\title{
The effect of marketing activities on gaining a competitive advantage with the mediating role of relationship quality; case study: Ansar Bank of Mashhad
}

\author{
Saeed Jafari Titkanloo ${ }^{1}$, Mahdi Ramzanpour ${ }^{2}$, Aria Fakour ${ }^{2}$ and Seyed Reza Nasri ${ }^{2}$ \\ ${ }^{1}$ Assistant professor, Faculty of Management, Imam Reza International University, Mashhad, Iran \\ ${ }^{2}$ Master of Business Administration, Imam Reza International University, Mashhad, Iran \\ Email:s_jafari_t@imamreza.ac.ir
}

\section{ABSTRACT}

The banking industry is experiencing an increasingly competitive atmosphere. The emergence of financial institutions and their entry into the competition arena have disrupted the existing security margin for banks. They have also challenged the guaranteed market share of many banks. Therefore, the purpose of the present research was to investigate the effect of marketing activities on gaining a competitive advantage with the mediating role of customer relationship quality at Ansar Bank, Mashhad, Iran. An applied research model with a descriptive survey design was used in this study. The statistical population of the research consists of the customers of the branches of Ansar Bank in Mashhad. The statistical population was selected using simple random sampling with the distribution of 400 questionnaires. Expert opinion was used to measure validity. Reliability measurement was performed using Cronbach's alpha which was calculated to be 0.93. Structural equation modeling (SEM) and LISREL were used for data analysis. The results suggest that marketing activities have a positive and significant effect on relationship quality and acquiring a competitive advantage. They also indicate that relationship quality has a significant effect on gaining a competitive advantage. Furthermore, it was revealed that

\section{Original Article}

PII: S232247702000004-10

Rec. 20 February, 2020

Acc. 29 May, 2020

Pub. 25 June, 2020

\section{Keywords}

Competitive advantage,

Relationship quality,

Marketing activities marketing activities have a positive and significant effect on acquiring a competitive advantage with the mediating role of relationship quality.

\section{INTRODUCTION}

Fierce competition is characteristic of the banking industry in the present age. In this regard, the most innovative products and services are replicated by competitors. This reduces the ability of banks to keep their sustainable competitive advantage. The emergence of financial institutions and their entry into the competition arena have disrupted the existing security margin for banks. They have also challenged the guaranteed market share of many banks. Financial institutions have been able to outperform banks in many areas to satisfy their customers and acquire a greater market share by relying on their marketing activities. These areas include offering modern banking services, extensive, creative and purposeful advertising, proper location allocation for the construction of their branches, designing attractive interiors and exteriors for their branches and most importantly careful recruitment and training of their employees. Marketing activities are some of the strategies capable of growing a bank's revenue (Taqiyah and Khatami, 2015).

Over recent decades the quality of a relationship has been considered to be an important topic in the area of business. Establishment of relationships with customers seems to be a necessity for organizations if they want to acquire a competitive advantage. To influence marketing activities and scientific research in various fields and industries the concept of relationship marketing has received attention. However, in the field of financial institutions and banks it has rarely been studied (Haghighi et al., 2012). In today's competitive environment, 
relationship quality is deemed to be one of the most important factors for the success of organizations (Noruznia, 2016). The concept of relationship marketing was first introduced in 1983 by Berry. Since then many empirical researchers and theorists consider the fundamentals of the marketing theory to be based on the following factors: a long-term and profitable relationship with customers (De Wulf et al., 2001), retaining current customers, developing and maintaining trust and commitment between sellers and customers (Gaur and $\mathrm{Xu}, 2009$ ) and extending the use of loyalty marketing strategies to establish profitable and long-term relationships with customers which leads to higher growth (Ferguson and Hlavinka, 2007). Fierce competition among commercial banks implies the short life cycle of innovative products and services because they are immediately replicated by competitors. Consequently, banks are more inclined to gain and maintain a sustainable competitive advantage (Gordon et al., 2008).

\section{Competitive advantage}

Competitiveness is a process where every institution tries to outperform and outgrow its competitors. The attainment of competitive capabilities in today's world has become one of the fundamental challenges of different countries at the international level. The concept of competitive advantage has different meanings and definitions which will be mentioned here. A competitive advantage is a distinction in the features or dimensions of any company that enables it to provide better services to its customers compared to its competitors. It is also the extra attractiveness of the company offers compared to the competitors from the perspective of its customers (Hosseini \& Shams, 2014). Porter defined a competitive advantage to be the values offered by a company to its customers in a way that these values are greater than customer costs. Given the above definitions and other available definitions, it can be discovered that a competitive advantage shows that the direct relationship of the desired values of a customer, the values offered by a company and the value offered by competitors determine the requirements and dimensions of a competitive advantage.
If from the perspective of a customer the values offered by a company compared to the values offered by its competitors are closer and more in alignment with his own expected values and requirements, then the following can be concluded: the company has a competitive advantage over its competitors in the market in one or more indicators. This competitive advantage makes the company better than its competitors in satisfying the customer and winning his heart.

Since the implementation of Iran's Third FiveYear Development Plan, the liberalization of the banking system by creating private banks was put on the agenda. The entry of banks and private financial institutions has led to an increase in the number of banks. Furthermore, some technologies such as credit cards, internet banking, mobile banking, etc. have been significantly developed. Hence, the competitive market in this industry has been completely transformed. Therefore, there is a growingly tight competition among banks for offering suitable banking services tailored to customers' needs and expectations (Sohrabi, 2016). Accordingly, to gain a competitive advantage an organization must pay attention to its external position and internal capabilities.

Two things must be considered when creating a competitive advantage. First, this is a continuous process that leads to the excellent and competitive performance of an organization. The organization can, in turn, use its competencies to create a sustainable competitive advantage that is valuable for its customers and always stay ahead of the competition. Second, due to increased environmental complexity and competition level, a competitive advantage will either be easily replicated by the competitors or will soon lose its attractiveness in the view of customers and should be replaced with new advantages. Hence, an organization must consider finding new competitive advantages (Davis, 2010). Sustainable competitive advantage is one of the most important topics in strategic management theories. This is because the existence of a competitive advantage in an organization enables it to outperform its competitors. In the short run, it guarantees profitability and in the long run, it guarantees organizational survival and growth. Moreover, the concept of competitive advantage is thought to be an eternal issue in strategic marketing literature. A competitive advantage in marketing is 
important because it causes market share to be increased and maintained and leads to the attainment of market leadership.

\section{Marketing activities}

The competition in Iran's banking industry is growing in intensity. In this competitive atmosphere, competitors always want to adopt appropriate strategies to attract and retain customers and increase and maintain their market share. The cost of retaining old customers is less than the cost of acquiring a new customer. As a result, the need for retaining current customers is very urgent. The emergence of private banks and their entry into the competition arena have disrupted the existing security margin for public banks. They have also challenged the guaranteed market share of many banks. Private banks have been able to outperform public banks in many areas to satisfy their customers and acquire a greater market share by relying on their innovative strategies. These areas include offering modern banking services, extensive, creative and purposeful advertising, appropriate location allocation for the construction of their branches, designing attractive interiors and exteriors for their branches and most importantly careful recruitment and training of their employees. In general, since private banks rely on their own profitability for survival and do not enjoy government support like public banks do they have been able to disrupt the steady state dominating the Iranian banking industry and create a competitive atmosphere. In this competitive atmosphere, competitors always want to utilize the most suitable tools and strategies to attract and retain customers and increase and maintain their market share (Tabatabai and Akhavan, 2010). Today, marketing strategies are one of the most important strategies for creating a change in market share particularly in the area of services (Abdekhoda, 2016). Marketing is one of the solutions that increase the revenues of banks. Effective marketing principles and techniques can be an effective tool to improve behavioral paradigms in the present competitive atmosphere. This is because of their applied approach to financial resources and banking utilities in offering performance and also because of their applied approach to customer relationship types and practical solutions for changing and improving traditional behaviors (Taqiyah and Khatami, 2015). By focusing on relationship marketing many banks try to grow beyond the core products and services provided by banks. One of the strategies often used by bank managers for this purpose is the strategy of quality enhancement using marketing strategies. What is usually neglected when improving the quality of banks is the establishment of relationships with customers. In other words, enhancing the quality of the relationships instead of the quality of services. In fact, it can be said that today with the arrival of relationship marketing and its strategies, increasing the quality of relationships through relationship marketing is one of the new areas in marketing research in the banking industry (Qareh, 2016).

\section{Customer relationship quality}

Relationship quality is recognized as a set of intangible values that lead to the expression of expected long-term relationships between two sides. Henning Torah \& Kelly describe the quality of relationships between customers and companies as follows: "the degree of a relationship's conformity with the needs of the customers involved in the relationship". The relationship between a service provider and customers depends on the quality of interactions between them (Ghaffari Ashtiani et al., 2012). Relationship quality (RQ) is a branch of relationship marketing. Due to the importance of relationship marketing (RM) in today's business world, relationship quality is necessary for evaluating the stability of a relationship and the degree of satisfaction from the provision of the demands and expectations of a customer (Crosby et al., 1990; Haghighi et al. 2012). Relationship quality can be defined as a set of intangible values that strengthen products and services and lead to the finalization of the expected deal between a customer and a seller (Al-Alak, 2014). To survive in today's competitive world particularly the service sector, banks must look for extra creativity with a greater level of effectiveness to attract and retain their visitors. One of the methods for the attraction and retention of visitors is to increase the relationship quality through mutual relations (Esmaeilpour et al., 2012). 


\section{\# METHODOLOGY}

\section{Main hypothesis}

Hypothesis 1: marketing activities have a positive effect on gaining a competitive advantage through the mediating role of customer relationship quality.

\section{Sub-hypotheses}

Hypothesis 2: marketing activities have a positive effect on relationship quality.
Hypothesis 3: marketing activities have a positive effect on gaining a competitive advantage.

Hypothesis 4: relationship quality has a positive effect on gaining a competitive advantage.

\section{Conceptual research model}

Finally, according to the research hypotheses the conceptual research model was designed as is displayed in figure 2 .

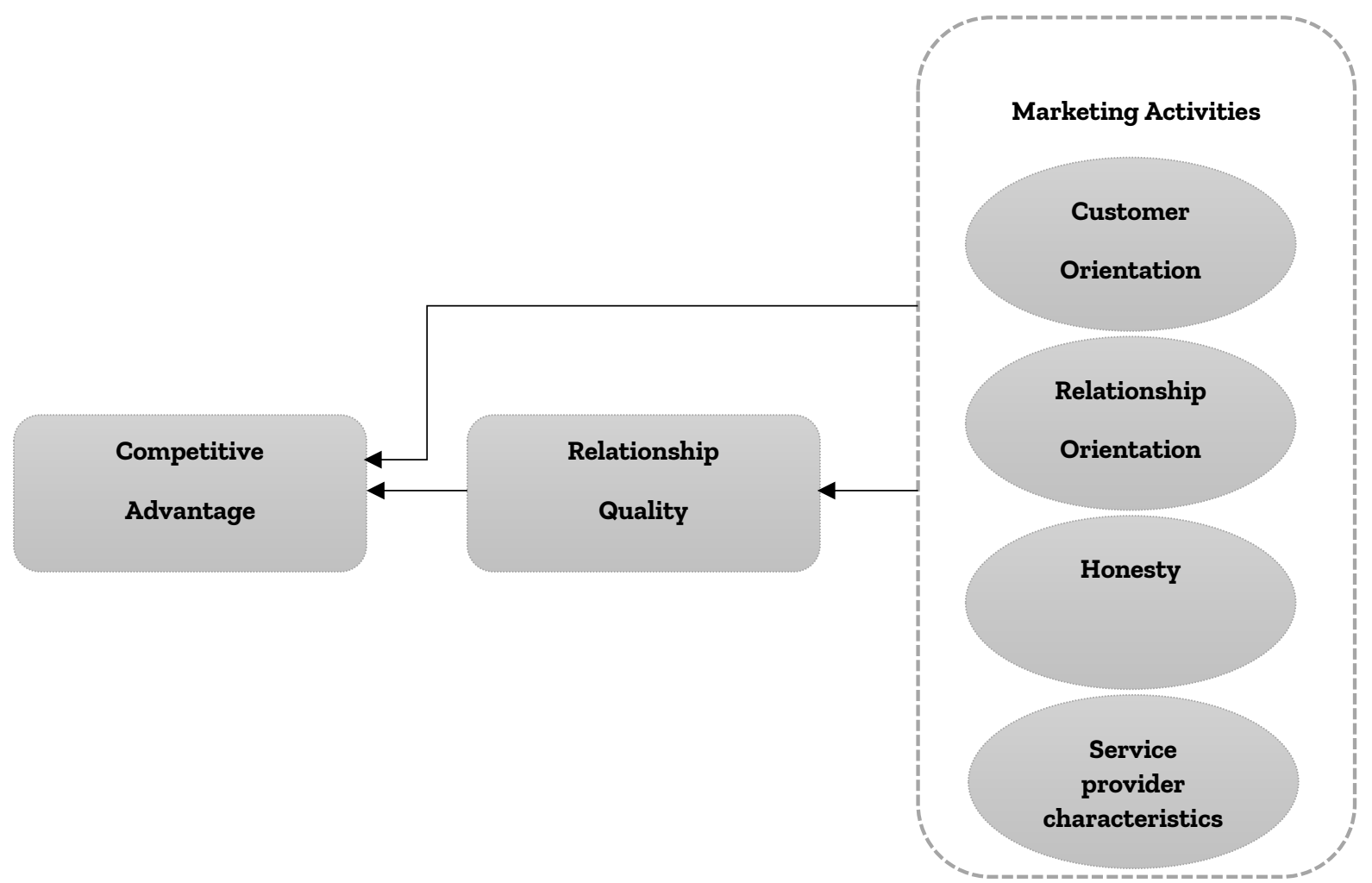

Figure 1. Conceptual research model

\section{H METHODOLOGY}

The present research employed an applied research model with a descriptive survey design for data collection. The statistical population of this research consists of the customers of the Mashhad branches of Ansar Bank. Using Morgan's table (Morgan and Hunt, 1998), the size of the population was calculated to be 384 . To be more certain, 420 questionnaires were distributed and collected. Only 384 of those questionnaires were usable which were then analyzed. In the present research, the survey data was collected using questionnaires. In this research, library studies were used for data collection utilizing a field survey. The data for this study were collected using questionnaires. The above questionnaire was prepared based on the questionnaires of Al-Alak (2013) and IsmailPour and Alizadeh (2013).

In order to confirm the face validity of the questionnaire, it was distributed to 10 senior Ansar Bank managers and also 8 MBA university professors. After collecting the questionnaires, the comments and suggestions of the senior managers and MBA professors were applied. The 
final questionnaire includes 5 demographic questions. 34 exclusive questions are about the variables of marketing activities, competitive advantage and relationship quality. The questions were evaluated using a 5-point.

Likert Scale ranging from "I complete agree" to "I completely disagree". In this study, 30 questionnaires were distributed to the statistical population to measure the reliability of the questionnaires. SPSS was used to measure Cronbach's alpha. The table 1 shows the results obtained for the Cronbach's alpha coefficient of each variable and the entire questionnaire is displayed. Based on the Cronbach's alpha coefficients of the variables, the reliability of the questions of every variable was confirmed. The overall Cronbach's alpha coefficient of the questionnaire was calculated to be 0.95 that indicates the validity and reliability of the research questionnaire. Internal validity includes construct validity, content validity and empirical validity. There are several techniques for construct validity, one of them being factorial validity which is obtained using factor analysis. The value obtained from factor analysis for each item must be higher than 0.3. As table 2 shows, the factor loading of each item in the research questionnaire is higher than 0.3. The content validity of this questionnaire was assessed by 10 senior Ansar Bank managers and $8 \mathrm{MBA}$ university professors. After their suggestions were applied the final questionnaire was submitted to the customers.

Table 1. Reliability and validity measurement.

\begin{tabular}{|c|c|c|c|c|c|c|}
\hline Variables & Indicators & Sub-indices & $\begin{array}{l}\text { Number of } \\
\text { questions }\end{array}$ & $\begin{array}{l}\text { Cronbach's } \\
\text { alpha }\end{array}$ & Items & $\begin{array}{c}\text { Factor } \\
\text { loading } \\
\text { scores }\end{array}$ \\
\hline \multirow{22}{*}{$\begin{array}{l}\text { Marketing } \\
\text { activities }\end{array}$} & \multirow{5}{*}{$\begin{array}{l}\text { Customer } \\
\text { orientation }\end{array}$} & \multirow{2}{*}{$\begin{array}{l}\text { Understanding } \\
\text { customer needs }\end{array}$} & \multirow{22}{*}{22} & \multirow{22}{*}{0.9} & 1 & 0.80 \\
\hline & & & & & 2 & 0.62 \\
\hline & & \multirow{3}{*}{ Conflict resolution } & & & 3 & 0.69 \\
\hline & & & & & 4 & 0.58 \\
\hline & & & & & 5 & 0.67 \\
\hline & \multirow{7}{*}{$\begin{array}{l}\text { Relationship } \\
\text { orientation }\end{array}$} & \multirow{2}{*}{ Cooperation level } & & & 6 & 0.62 \\
\hline & & & & & 7 & 0.72 \\
\hline & & \multirow{5}{*}{ Empathy level } & & & 8 & 0.59 \\
\hline & & & & & 9 & 0.77 \\
\hline & & & & & 10 & 0.72 \\
\hline & & & & & 11 & 0.62 \\
\hline & & & & & 12 & 0.71 \\
\hline & \multirow{4}{*}{\multicolumn{2}{|c|}{ Mutual relations (honesty) }} & & & 13 & 0.59 \\
\hline & & & & & 14 & 0.62 \\
\hline & & & & & 15 & 0.80 \\
\hline & & & & & 16 & 0.79 \\
\hline & \multirow{6}{*}{$\begin{array}{l}\text { Service providers' } \\
\text { characteristics }\end{array}$} & \multirow{2}{*}{ Specialization } & & & 17 & 0.64 \\
\hline & & & & & 18 & 0.55 \\
\hline & & Experience & & & 19 & 0.72 \\
\hline & & \multirow{3}{*}{$\begin{array}{l}\text { Personal } \\
\text { appearance }\end{array}$} & & & 20 & 0.79 \\
\hline & & & & & 21 & 0.89 \\
\hline & & & & & 22 & 0.89 \\
\hline \multirow{8}{*}{$\begin{array}{l}\text { Relationship } \\
\text { quality }\end{array}$} & \multirow{3}{*}{\multicolumn{2}{|c|}{ Satisfaction }} & \multirow{8}{*}{8} & \multirow{8}{*}{0.85} & 23 & 0.85 \\
\hline & & & & & 24 & 0.74 \\
\hline & & & & & 25 & 0.44 \\
\hline & \multirow{5}{*}{ Trust } & & & & 26 & 0.52 \\
\hline & & & & & 27 & 0.44 \\
\hline & & & & & 28 & 0.45 \\
\hline & & & & & 29 & 0.66 \\
\hline & & & & & 30 & 0.47 \\
\hline \multirow{4}{*}{\multicolumn{3}{|c|}{ Competitive advantage }} & \multirow{4}{*}{4} & \multirow{4}{*}{0.87} & 31 & 0.73 \\
\hline & & & & & 32 & 0.57 \\
\hline & & & & & 33 & 0.38 \\
\hline & & & & & 34 & 0.32 \\
\hline Total questionn & cores & & 34 & 0.93 & & \\
\hline
\end{tabular}




\section{Demographic characteristics of the sample}

In the present research, 420 questionnaires were distributed and collected. Only 384 of those questionnaires were usable which were analyzed. The questionnaire respondents' characteristics were considered and evaluated using the variables of gender, age, level of education, deposit term and account type. $85.2 \%$ of the respondents were male and $14.8 \%$ were female. The majority of them were 30 to 40 years old (65\%) and a small number of them were 50 and older (5\%). The level of education with the highest frequency was the undergraduate level (47\%) whereas the lowest frequency belonged to the doctorate level (3\%).

The results from the general questions of the questionnaire revealed that nearly $47 \%$ of the customers who completed the questionnaire have been Ansar Bank's customers for more than 8 years. The lowest frequency with only $2 \%$ belongs to customers with less than one year since opening their deposit account. Moreover, $12 \%$ of the customers participating in the questionnaire have a long-term deposit account and 54\% of them have a short-term deposit account and 34\% of them have short-term and long term accounts.

\section{Inferential statistics}

Structural equation modeling (SEM) is used to show, estimate and test hypotheses regarding the causal relationship between observed and latent variables. This technique has two parts namely a measurement model and a structural model. In the first part being the measurement model, it assesses the validity (credibility) and reliability (trust) of latent research variables. Average variance extracted (AVE) is used for validity. In the second part, the structural model is used to evaluate the causal relationships between the latent variables (constructs) of the research (Haghparast et al. 2014).

The structural model in the software output has been evaluated in the two states of the standard error (SE) of the estimate and statistical significance (T-Values). First, the model was assessed in the state of the SE of a statistic. In the state of the SE, the coefficients are converged. This means that their measure has been unified and it is possible to compare them. Any path coefficient in the structural model can be considered to be equal to a standardized beta coefficient in the Ordinary Least Squares (OLS) regression.

Table 2. Factor analysis results for hypotheses testing.

\begin{tabular}{|c|c|c|c|c|}
\hline Hypotheses & Relationships being tested & $\begin{array}{l}\text { Path } \\
\text { coefficient }\end{array}$ & t-statistic & Result \\
\hline Main hypothesis & $\begin{array}{l}\text { Marketing activities have a positive } \\
\text { effect on gaining a competitive } \\
\text { advantage through the mediating role } \\
\text { of customer relationship quality }\end{array}$ & 0.38 & 38.08 & Confirmed \\
\hline Sub-hypothesis 1 & $\begin{array}{l}\text { Marketing activities have a positive } \\
\text { effect on relationship quality }\end{array}$ & 0.86 & 10.13 & Confirmed \\
\hline Sub-hypothesis 2 & $\begin{array}{l}\text { Marketing activities have a positive } \\
\text { effect on gaining a competitive } \\
\text { advantage }\end{array}$ & 0.27 & 2.43 & Confirmed \\
\hline Sub-hypothesis 3 & $\begin{array}{l}\text { Relationship quality has a positive } \\
\text { effect on gaining a competitive } \\
\text { advantage }\end{array}$ & 0.45 & 3.76 & Confirmed \\
\hline
\end{tabular}


Sub-hypothesis 1: marketing activities have a positive effect on customer relationship quality

Based on the analysis, it was concluded that there is a significant and positive effect between marketing activities and customer relationship quality. Marketing activities in the dimensions of customer orientation, relationship orientation, mutual relationships and also the sub-indices of specialization and personal appearance of the employees of Ansar Bank of the characteristics of service providers have a positive effect on increasing customer relationship quality. This result is in alignment with the findings of Al-Alak (2006).

Sub-hypothesis 2: marketing activities have a positive effect on gaining a sustainable competitive advantage.

Based on the analysis, it was discovered that there is a significant and positive relationship between marketing activities and gaining a competitive advantage. Therefore, it can be claimed that marketing activities have a significant and positive effect on gaining a sustainable competitive advantage. A competitive advantage consists of the values that a company can provide to its customers in a manner that these values will be higher than the customer costs. Marketing is one of the solutions that increase the revenues of banks. Effective marketing principles and techniques can be an effective tool to improve behavioral paradigms in the present competitive atmosphere. This is because of their applied approach to financial resources and banking utilities in offering performance and also because of their applied approach to customer relationship types and practical solutions for changing and improving traditional behaviors. The positive and significant relationship between marketing activities and gaining a competitive advantage matches the results obtained in the research paper of Maleki Vier (2017).

Sub-hypothesis 3: customer relationship quality has a positive effect on gaining a competitive advantage.

Based on the analysis, it was concluded that there is a positive and significant relationship between marketing activities and gaining a competitive advantage. The research hypothesis stating that a competitive advantage based on the internal capabilities of an organization is the best source for a competitive advantage is confirmed. Hence, the selection of this approach for analyzing and investigating the source of competitive advantage is a tried and tested method. The quality of services received by customers and also the quality of their relationship with service providers and the company will lead to positive customerrelated outcomes. Relationship quality is considered to be the positive emotions of customers about a service provider, their relationship with the service provider based on trust and commitment. It also consists of their overall satisfaction of the service provider. The dimensions of satisfaction and trust of the variable of relationship quality which leads to customer satisfaction and loyalty have a positive effect on gaining a competitive advantage. This is in alignment with the results of the studies of Al-Alak (2006).

Main hypothesis: marketing activities have a positive effect on gaining a sustainable competitive advantage through relationship quality.

According to the sub-hypotheses of this study and the Baron and Kenny method, we can deduce that marketing activities (independent variable) have a positive and significant effect on gaining a competitive advantage (dependent variable) through the mediating role of customer relationship quality (mediator variable). This confirms the main research hypothesis. The dimensions of marketing activities including customer orientation, relationship orientation, customer-employee relationships and the characteristics of service providers that focus on customers as well as a permanent and effective relationship with them will lead to the understanding of customer needs. They also lead to cooperation and empathy with customers and help resolve conflicts with them. This enhances relationship quality, establishes and improves a permanent and effective relationship with 
customers and results in the satisfaction and loyalty of customers.

As it was stated in chapter 2, bank services and innovations in the fierce competition arena of banks are quickly replicated and have a short life cycle. However, focusing on customers and making them the center of attention and establishing a permanent and effective relationship with them will bring about their satisfaction and loyalty. So we will be able to gain a sustainable competitive advantage. We will also be able to increase our market share. In the short run doing this guarantees profitability for an organization and in the long run guarantees organizational survival.

\section{* CONCLUSION AND SUGGESTIONS}

Based on the results inferred from the research hypotheses, the following recommendations can be offered:

- Employees must possess the required experiences and specialization. They must have a suitable personal appearance. They should also fulfill the banking operations requested by a customer in a quick, precise and high-quality manner. Employees should treat customers respectfully. These will help establish an effective and permanent relationship with customers and attain their satisfaction and loyalty which belong to the dimension of customer relationship quality.

- Customer relationship quality can affect competitive advantage attainment. Hence, employees are recommended to place customers in the center of their attention and focus on customer acquisition and retention.

- Once customer satisfaction is realized and intimate and permanent relationships between employees and customers are continuously strengthened it will lead to the loyalty of customers to an organization. It will increase and maintain market share, lead to the attainment of a sustainable competitive advantage over other competitors and ultimately result in profitability.

- In the past and in the traditional banking system, the highest degree of attention was given to performing banking operations and bank facilities and deposit plans. But now the greatest amount of attention is given to customers and the creation and maintenance of a permanent relationship with them. Therefore, given the positive relationship between marketing activities and sustainable competitive advantage attainment it can be recommended that by focusing on customers and discovering their needs and expectations and trying to meet their needs and demands in a quick, precise and high-quality manner and by guiding them and showing empathy to them we can gain a sustainable competitive advantage over other competitors.

- The purpose of this study was to gain a sustainable competitive advantage in the competition arena between banks. This can be achieved through marketing activities and relating dimensions which result in customer relationship quality enhancement. Therefore, it is recommended to consider customer orientation and train employees to help them acquire the necessary experience and specialization and also pay attention to their personal appearance. Employees must also learn to respect customers. All of this will help a bank gain a sustainable competitive advantage over other banks.

- Employees are recommended to establish a more intimate and effective relationship in the next visit by a customer compared to the last visit to their branch. Furthermore, by remembering and calling a customer by his last name and welcoming him in an intimate manner, employees they will create the foundation for the loyalty of the customer.

\section{\# REFERENCES}

Abdekhoda, A. (2016). The Effect of Marketing Strategies on Bank Marketing Performance. Management Studies and Entrepreneurship. (2), 132-146.

Al-Alak. B.A. (2006). The Impact of Marketing Actions on Relationship Quality in the Higher Education Sector in Jordan. Journal of Marketing. (16), 1-24.

Al-Alak. B.A. (2014). Impact of marketing activities on relationship quality in the Malaysian banking sector. Journal of Retailing and Consumer Services , (21), 347-356. 
Crosby, L., Evans, K., \& Cowles, D. (1990). Relationship Quality in Services Selling: An Interpersonal Influence Perspective. Journal of Marketing, (68), 68-81 Google Scholar, https://doi.org/10.1177/002224299005400306

Davis, S. (2010). Stevens out to prove Butler belongs among the nation's elite. Retrieved November, 2010 Kaleka, Anna, Resources and capabilities driving competitive advantage in export markets: guidelines for industrial exporters, Industrial Marketing Management,( 31), 273-283.

Dwyer, F.R., Schurr, P.H., \& Oh, S. (1987). Developing buyer - seller relations. Journal of Marketing, 51(2), 11-27. Google Scholar, https://doi.org/10.1177/002224298705100202

Esmaeilpour, H., Javanmard, H., and Bajalan, A. (2012). Investigating the effect of respect and understanding on the quality of perceived communication by clients of small health care institutions. Case study: Dentistry in Arak. Marketing Management, (15), 146-131.

Ferguson, R. Hlavinka, K (2007). Choosing the right tools for your relationship banking strategy. Journal of Consumer Marketing (24).110-117. Google Scholar, https://doi.org/10.1108/07363760710737111

Gaur, S., and $\mathrm{Xu}, \mathrm{Y}$. (2009). Consumer Comfort and Its Role in Relationship Marketing Outcomes: An Empirical Investigation. Advances in Consumer Research - Asia- Pacific Conference Proceedings. 8, 296-298. Google Scholar

Ghaffari Ashtiani, P., Chainari, M., and Panahi Vanani, M. (2012). Investigate the impact of quality of communication and customer understanding on positive verbal statements. Marketing Management Magazine. https://magiran.com/p11606o6

Gordon, T. L. O., Pires, G. D., \& Stanton, J. (2008). The relationship marketing orientation of Hong Kong financial services industry managers and its links to business performance. Journal of Financial Services Marketing, 13(3), 193-203.

Haghighi, M., Hosseini, H., Asghari Ahari, H., Aryan, A., and Derekandeh, A. (2012). Investigating the Effect of Relational Marketing Tactics on Customer Loyalty from Irancell Customers Perspective. New Marketing Research, (7), 60-43.

Haghparast, R., and Hedayati Nia, S., and Khosravi Pur, B. (2014). Structural Equation of Effective Factors on the Acceptance of Information and Communication Technology among Graduate Students in Agriculture and Natural Resources,
Ramin Ahwaz. Agricultural Research Management Education Quarterly. (6) .49-62

Hosseini, A., and Shams, F. (2014). The Effect of Positive Organizational Behavior and Innovation by Improving Competitive Advantage. Improvement Management Studies. (75), 159-137.

IsmailPour, M., and Alizadeh, M. (2013). Investigating the Effect of Customer Relationship Management on the Quality Dimensions of the Relationship from the Perspective of Iranian Insurance Industry Customers. New Marketing Research. (16), 29-44.

Malekivier, M. (2017). Investigating the effect of relational marketing on the competitive advantage of Bank Mellat branches. Science and Engineering Elite. (5), 11-37.

Morgan, RM., Hunt, S. (1998). The Commitment Trust Theory of Relationship Marketing, Journal of Marketing 58:2038.

Noruznia, A. (2016). Examining the relationship between service quality and maintaining existing customers from the perspective of CRM. Management Studies and Entrepreneurship Studies. (1)2, 161-174.

Qareh, M. (2016). The Effect of Marketing Activities on the Quality of Relationships with Customers (Case Study: Agricultural Bank). Shahid Beheshti University, Faculty of Management and Accounting.

http://library.sbu.ac.ir/islandora/object/thesis\%3A3 $\underline{8403}$

Smith, JB. (1998). BuyerSeller Relatioships: Similarity, Relationship Management, and Quality. Psychology and Marketing 15(1):321. Google Scholar, https://doi.org/10.1002/(SICI)15206793(199801)15:1<3::AID-MAR2>3.0.CO;2-I

Sohrabi, P. (2016). Investigating the Effect of Organizational Intelligence on Competitive Advantage at National Bank of Iran. Quarterly journal of recent research in humanities. (14), 11495.

Tabatabai, S V., and Akhavan, N. (2010). Investigating the Relationship between Internal Marketing and Service Quality: A Case Study of Agricultural Bank. National Conference on Management and Leadership Challenges in Iranian Organizations at Islamic Azad University, Isfahan Science and Research Branch. https://www.civilica.com/PaperCMPIOO1-CMPIOO1 075.html

Taqiyah, S., and Khatami, S K. (2015). Effectiveness Techniques of Banking Resources and Banking Marketing. International Conference on New 
Approaches to Economic Accounting Management. https://www.civilica.com/Paper-ACONFo1-

ACONFO1 046.html

De Wulf, K., Odekerken-Schröder, G., \& Iacobucci, D. (2001). Investments in consumer relationships: A cross-country and cross-industry exploration. Journal of marketing, 65(4), 33-50. Googhle Scholar, https://doi.org/10.1509/jmkg.65.4.33.18386 